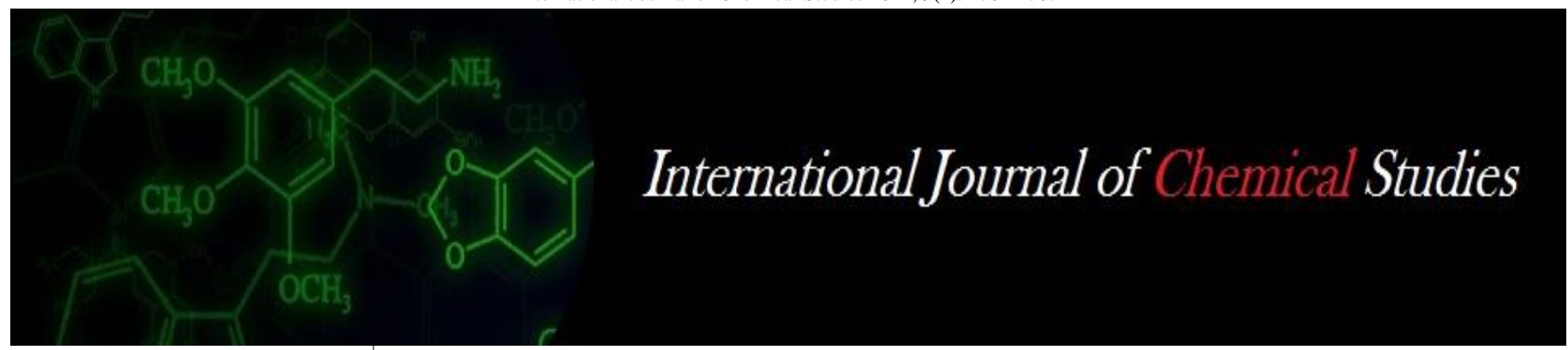

P-ISSN: 2349-8528

E-ISSN: 2321-4902

www.chemijournal.com

IJCS 2021; 9(1): 2762-2767

(C) 2021 IJCS

Received: 01-10-2020

Accepted: 12-11-2020

Madaraboina Venkateswara Rao Department of Food

Engineering, Indian Institute of Food Processing Technology,

Thanjavur, Tamil Nadu, India

\section{Akhil KG}

Department of Food

Engineering, Indian Institute of

Food Processing Technology,

Thanjavur, Tamil Nadu, India

\section{Sunil CK}

Department of Food

Engineering, Indian Institute of

Food Processing Technology,

Thanjavur, Tamil Nadu, India

\section{Venkatachalapathy $\mathbf{N}$}

Department of Food

Engineering, Indian Institute of

Food Processing Technology,

Thanjavur, Tamil Nadu, India

\section{Jaganmohan $\mathbf{R}$}

Department of Food Product

Development, Indian Institute of

Food Processing Technology,

Thanjavur, Tamil Nadu, India

\section{Corresponding Author:}

Sunil CK

Department of Food

Engineering, Indian Institute of

Food Processing Technology,

Thanjavur, Tamil Nadu, India

\section{Effect of microwave treatment on physical and functional properties of foxtail millet flour}

\author{
Madaraboina Venkateswara Rao, Akhil KG, Sunil CK, \\ Venkatachalapathy $\mathbf{N}$ and Jaganmohan $\mathrm{R}$
}

DOI: https://doi.org/10.22271/chemi.2021.v9.i1am.11641

\begin{abstract}
Foxtail millet is one of the common millets used for multiple purposes in India. It contains a good amount of fiber along with other nutrients and thus serves as a digesting aid. Because of its diversified benefits, foxtail millet has a wide range of applications in the bakery, brewery, and beverage industries. The application of novel thermal technologies to maintain and improve the nutritional and quality characteristics is of great importance in recent days. The present study investigates the application of microwave pre-treatment to the foxtail millet and understanding of its effects on physical and functional properties. Physical properties like tapped density, bulk density, Carr's index, and Hausner ratio didn't show any difference in the obtained values. Even though, there was a noticeable change in color of microwave treated flour, that didn't show any impact on its visual appearance. Oil absorption capacity decreased with microwave treatment while water absorption capacity resulted increased. Swelling power decreased with an increase in power level and time. However, the solubility of flour increased with microwave treatment and the highest solubility was noticed at $840 \mathrm{~W}$ and 2 min treatment conditions.
\end{abstract}

Keywords: Microwave, physical and functional properties, foxtail millet flour

\section{Introduction}

Millets refers to small-seeded annual cereal grains and consumed as a staple food for millions of people mainly those who live in the part of arid and semiarid regions of the world. Among various millet varieties, foxtail millet (Setaria italica) is one of the most important and oldest cultivated millet species and is also recognized as the sixth-highest yielding grain. Foxtail millet is also named as Italian millet which belongs to the Poaceae family of Setaria genius (Sunil et al., 2016) ${ }^{[19]}$. Foxtail millet gains prominence because of its many health benefits like hypoglycaemic effects, prevention of cancer, and hypolipidemic effects, and these benefits are primarily attributed to the presence of antioxidants in the form of phenolics and carotenoids (i.e., phytochemicals), which induces a deactivation of free radicals inside the human body (Sharma et al., 2018) ${ }^{[13]}$.

The nutritional profile of foxtail millet is also superior to the staple cereals (rice and wheat), and possess comparable contents of protein (12-19\%), fat (5-9\%), soluble fiber (3-4\%), minerals $(3.3 \%)$, iron $(2.8 \%)$ and calcium $(31 \%)$. It also a greater source of vitamins and phytochemicals like riboflavin, thiamine, niacin, folacin, and $\beta$-carotene (Sunil \& Venkatachalapathy, 2017) ${ }^{[18]}$.

Morphologically, the endosperm of foxtail millet is encased in a tough outer aleurone layer along with a husk portion of $13.5 \%(\mathrm{w} / \mathrm{w})$ as a distinct entity. The foxtail millet needs to be milled to separate the inedible husk prior to its consumption as similar to rice. Moreover, the majority of fiber, phenolics, and phytates are also concentrated in the layers of a pericarp, seed coat, and aleurone of the grain which hinders the nutrient absorption of millets to the body. These anti-nutrients can be reduced by using simple processing methods such as milling, germination, roasting, and other further heat treatments (dry, and wet) to enhance its texture and cooking quality (Umesha et al., 2015) ${ }^{[20]}$.

Over the decades, the foxtail millet was processed by conventional methods to improve its edible, nutritional, and sensory properties. Recently, microwave processing has come into a light to enhance the physicochemical accessibility of micro and macronutrients by improving the dehulling efficiency (Sunil \& Chacko, 2019) ${ }^{[17]}$ and reducing the anti-nutritional factors. 
Moreover, microwave processing is also the most suitable technique because of its faster drying rate, uniform and rapid heating, lesser time, precise control, and low operational cost and time (Devraj et al., 2020; Naik et al., 2021) ${ }^{[2,8]}$. Even though foxtail millet consumption and utilization are limited because of their insufficient availability of ready-to-cook, and ready-to-eat millet products as are available for rice and wheat. The majority of the processed foxtail millets are marketed in the form of rice, flour, or semolina (like rava). But, there is a greater scope of its exploitation in the development of various food products including baked products like biscuits, cookies, cakes, bread, muffins, pies, pancakes, snacks, extruded foodstuffs, and breakfast cereals (idli, dosa, papad, and chakli) which is primarily dependent on its flour functionality (Karuppasamy et al., 2013) ${ }^{[4]}$.

Considering the scope and demand of novel food ingredients and processing technologies efforts have been made to investigate the effects of microwave treatment on the physical and functional properties of foxtail millet flour. We believed that the microwave treated foxtail millet flour serves as a "novel food ingredient" for the development of various processed food products. In this study, we have explored the effect of microwave pre-treatment prior to milling on physical (Color, Bulk density, Tapped density, Carr's index, and Hausner ratio) and functional properties such as water and oil absorption capacities, solubility, and swelling capacity of foxtail millet flours and their quality.

\section{Material and methods}

\subsection{Materials}

Foxtail millet grains (Setaria italic L) were procured from Thanjavur local market, Tamilnadu. The grains were cleaned with an 850-micron sieve (ASTM No. 20) in a mechanical sieve shaker to separate foreign impurities and damaged kernels. The cleaned sample was packed tightly in a zip-lock polyethylene bag and stored in a dry place at room temperature $\left(30 \pm 2^{\circ} \mathrm{C}\right)$ for further processing.

\subsection{Microwave treatment of foxtail millet grains and milling}

Foxtail millet grains of $500 \mathrm{~g}$ were conditioned to $24 \%$ (w.b.) from initial moisture of $10 \pm 0.5 \%$ (w.b.) by adding the desired quantity of double distilled water $(92.1 \mathrm{ml})$ according to the methodology given by Yadav et al., (2012) ${ }^{[21,22]}$. The conditioned foxtail millets $(250 \mathrm{~g})$ were spread uniformly (grain thickness: $1.6 \pm 0.1 \mathrm{~cm}$ ) in the petri plates and allowed for microwave treatment.

The domestic microwave (MW) oven (Model: 30 SC2, IFB, India) having an operating frequency of $2450 \mathrm{MHz}$ with a maximum input power of $1400 \mathrm{~W}$ and rated output power of $900 \mathrm{~W}$ was used for treatment. The conditioned foxtail millet grains of $24 \%$ (w.b.) moisture was used for microwave (MW) treatment at the ambient condition with varying power levels (720, 810, and $900 \mathrm{~W})$ for different exposure times $(2,4$, and $6 \mathrm{~min})$. The treated millet grains were cooled and dried to constant moisture of $11.5 \pm 0.5 \%(\mathrm{wb})$ at room temperature. Furthermore, the dried grains were dehusked in a laboratory abrasive (emery roll) polisher (Model: TM 05, Satake Corporation, Japan). The dehusked millets were cleaned by air winnowing for removal of dust and husk material before the grinding. The dehusked millet grains were pulverized into a fine flour using a laboratory mill and sieved using a 500micron sieve for uniform size particles. The foxtail millet flour (< 500 microns) was used for further analysis and the whole experiments were carried out in triplicates.
The samples were named as $\mathrm{C}$ (Control), $\mathrm{T}_{1}(720 \mathrm{~W}-2 \mathrm{~min}), \mathrm{T}_{2}$ (720W-4 min), $\mathrm{T}_{3}(720 \mathrm{~W}-6 \mathrm{~min}), \mathrm{T}_{4}(840 \mathrm{~W}-2 \mathrm{~min}), \mathrm{T}_{5}$ (840W-4 min), $\mathrm{T}_{6}(840 \mathrm{~W}-6 \mathrm{~min}), \mathrm{T}_{7}(900 \mathrm{~W}-2 \mathrm{~min}), \mathrm{T}_{8}$ (900W-4 min) and $\mathrm{T}_{9}(900 \mathrm{~W}-6 \mathrm{~min})$.

\subsection{Physical properties}

\subsubsection{Color}

The color values of samples were estimated using a hunter lab colorimeter (Colourflex EZ model: 4510, Hunter Associates Laboratory, Reston, VA). The color values were calibrated with a white tile $(X=80.06, Y=85.06, Z=89.63)$ and a black tile as a standard supplied by the manufacturer before experimenting. The $\mathrm{L}^{*}, \mathrm{a}^{*}, \mathrm{~b}^{*}$ values (where $\mathrm{L}^{*}$ - lightness to darkness; $a *$ - redness to greenness; $b *_{\text {- }}$ yellowness to blueness) of a millet flours were recorded. The total color differences $(\Delta E)$ between the different FMF samples were calculated according to (Khushbu et al., 2020) ${ }^{[5]}$.

\subsubsection{Bulk density and Tapped density}

Control and MW treated flours were analyzed for bulk density and tapped density according to (Smita et al., 2019) ${ }^{[15]}$. Briefly, a graduated cylinder of $100 \mathrm{ml}$ was taken and filled with flours up to the mark of $100 \mathrm{ml}$. Afterward, the weight of the cylinder was noted to calculate the bulk density $(\mathrm{g} / \mathrm{ml})$, and then the cylinder was tapped 10 times on the flat surface to allow the flow particles get settle. Tapped density $(\mathrm{g} / \mathrm{ml})$ was calculated from the final weight of tapped cylindrical tube after filling the material up to a $100 \mathrm{ml}$ volume.

\subsubsection{Carr's index (CI) and Hausner ratio (HR)}

Carr's index (CI) and Hausner ratio (HR) indicates the compressibility and cohesiveness of the millet flour particles. These were measured with the values of bulk and tapped densities as per the equations ( $1 \& 2)$ given by (Smita et al., 2019) ${ }^{[15]}$.

$$
\mathrm{CI}=\frac{\text { Tapped density-Bulk density }}{\text { Tapped density }} \times 100
$$

$$
\mathrm{HR}=\frac{\text { Tapped density }}{\text { Bulk density }}
$$

\subsection{Functional properties}

\subsubsection{Water and oil absorption capacities:}

The water absorption capacity (WAC) and oil absorption capacity (OAC) of the FMF were measured according to (Nikitha \& Natarajan, 2020) ${ }^{[9]}$. Briefly, 1 gram of FM flour sample was precisely weighed and added to a centrifuge tube containing $10 \mathrm{ml}$ of either water or refined sunflower oil and mixed thoroughly for $30 \mathrm{sec}$. The sample was kept aside at room conditions for $30 \mathrm{~min}$ without stirring followed by centrifugation of the sample at $2000 \mathrm{rpm}$ for $30 \mathrm{~min}$. The supernatant was removed and the tubes with pellets were weighed. The water/oil absorption capacity (OAC/WAC) values were calculated from the increase in weight of the sample and are indicated as a gram of water/oil absorbed by the gram (d.b.) of the sample.

\subsubsection{Swelling power (SP) and water Solubility index (S)} The swelling power (SP) and solubility (S) of FMF were measured by heating a flour-water slurry $(0.5 \mathrm{~g}$ flour in a 15 $\mathrm{mL}$ of distilled water) in a water bath at $90^{\circ} \mathrm{C}$ for $30 \mathrm{~min}$, with continuous stirring (Obadi et al., 2018) ${ }^{[11]}$. The resulting flour-water slurry was cooled to ambient temperature and 
centrifuged at $4000 \mathrm{rpm}$ for $15 \mathrm{~min}$. The supernatant was decanted into a weighed evaporating petri dish and dried at $100^{\circ} \mathrm{C}$ for $20 \mathrm{~min}$. The weight of dried supernatant and sediment was noted. The percentage solubility (S\%) and swelling power $(\mathrm{SP} \mathrm{g} / \mathrm{g})$ on a dry basis were determined as per equations ( $3 \& 4)$ given below:

$$
\mathrm{S}(\%)=\frac{\text { dry supernatant weight }}{\text { weight of a dry sample }} \times 100
$$

$$
\mathrm{SP}\left(\frac{\mathrm{g}}{\mathrm{g}}\right)=\frac{\text { sediment weight } \times 100}{\text { dry sample weight } \times(100-\mathrm{S} \%)}
$$

\subsection{Statistical analysis}

All the statistical analyses required for the experimental results were performed using Minitab statistical software (Version 17.0). One-way analysis of variance (ANOVA) with multiple comparisons was used to compare the data obtained from various treatments. Tukey's pairwise comparisons was performed to establish a probability level of $p \leq 0.05$ for considering significance. All the experiments were performed in triplicates and values were reported as mean \pm standard deviation.

\section{Results and discussions}

\subsection{Effect of microwave treatment on physical properties}

\subsubsection{Tapped density and bulk density}

From the experimental study, it was noticed that the tapped density of flour samples was higher than the bulk density as it at all the treatment levels and in the control sample, as the volume of voids become negligible due to external force applied (Smita et al., 2019) ${ }^{[15]}$. In the case of tapped density, some of the treated samples resulted in higher values compared to untreated flour. Flour treated at $720 \mathrm{~W}$ for $2 \mathrm{~min}$ showed higher tapped density $(0.734 \pm 0.055 \mathrm{~g} / \mathrm{mL})$ compared to control $(0.702 \pm 0.005 \mathrm{~g} / \mathrm{mL})$. However, no statistical difference was found between the highest value reported and samples treated at $840 \mathrm{~W}$. Tapped density decreased with increasing treatment time at 720 and $900 \mathrm{~W}$, while the trend in $840 \mathrm{~W}$ treatments was unclear. On the other hand, there was no significant difference found between the bulk density of treated and untreated flour as explained in table 1.

Increasing the power level and treatment time did not report any notable difference in the BD and TD of sample flours $(\mathrm{P}>0.05)$. Table 1 represents the values obtained for bulk and tapped densities in treated and untreated samples.

Table 1: Bulk density and tapped density of microwave treated foxtail millet flour

\begin{tabular}{|c|c|c|}
\hline Treatment conditions & BD $(\mathbf{g} / \mathbf{m l})$ & TD $(\mathbf{g} / \mathbf{m l})$ \\
\hline Control & $0.61 \pm 0.006^{\mathrm{a}}$ & $0.70 \pm 0.005^{\mathrm{b}}$ \\
\hline T1 $(720 \mathrm{~W}-2 \mathrm{~min})$ & $0.64 \pm 0.012^{\mathrm{a}}$ & $0.73 \pm 0.051^{\mathrm{a}}$ \\
\hline T2 $(720 \mathrm{~W}-4 \mathrm{~min})$ & $0.63 \pm 0.007^{\mathrm{a}}$ & $0.71 \pm 0.011^{\mathrm{b}}$ \\
\hline T3 $(720 \mathrm{~W}-6 \mathrm{~min})$ & $0.61 \pm 0.003^{\mathrm{a}}$ & $0.71 \pm 0.002^{\mathrm{b}}$ \\
\hline T4 $(840 \mathrm{~W}-2 \mathrm{~min})$ & $0.62 \pm 0.008^{\mathrm{a}}$ & $0.72 \pm 0.006^{\mathrm{ab}}$ \\
\hline T5 $(840 \mathrm{~W}-4 \mathrm{~min})$ & $0.62 \pm 0.003^{\mathrm{a}}$ & $0.71 \pm 0.006^{\mathrm{ab}}$ \\
\hline T6 $(840 \mathrm{~W}-6 \mathrm{~min})$ & $0.63 \pm 0.007^{\mathrm{a}}$ & $0.72 \pm 0.007^{\mathrm{ab}}$ \\
\hline T7 $(900 \mathrm{~W}-2 \mathrm{~min})$ & $0.61 \pm 0.034^{\mathrm{a}}$ & $0.72 \pm 0.004^{\mathrm{ab}}$ \\
\hline T8 $(900 \mathrm{~W}-4 \mathrm{~min})$ & $0.61 \pm 0.005^{\mathrm{a}}$ & $0.71 \pm 0.021^{\mathrm{ab}}$ \\
\hline T9 $(900 \mathrm{~W}-6 \mathrm{~min})$ & $0.61 \pm 0.004^{\mathrm{a}}$ & $0.70 \pm 0.003^{\mathrm{b}}$ \\
\hline
\end{tabular}

All the data are expressed in the form of mean \pm standard deviation; Means that do not share a common alphabet are significantly different $p \geq 0.05$.

\subsubsection{Effect of microwave treatment on color values}

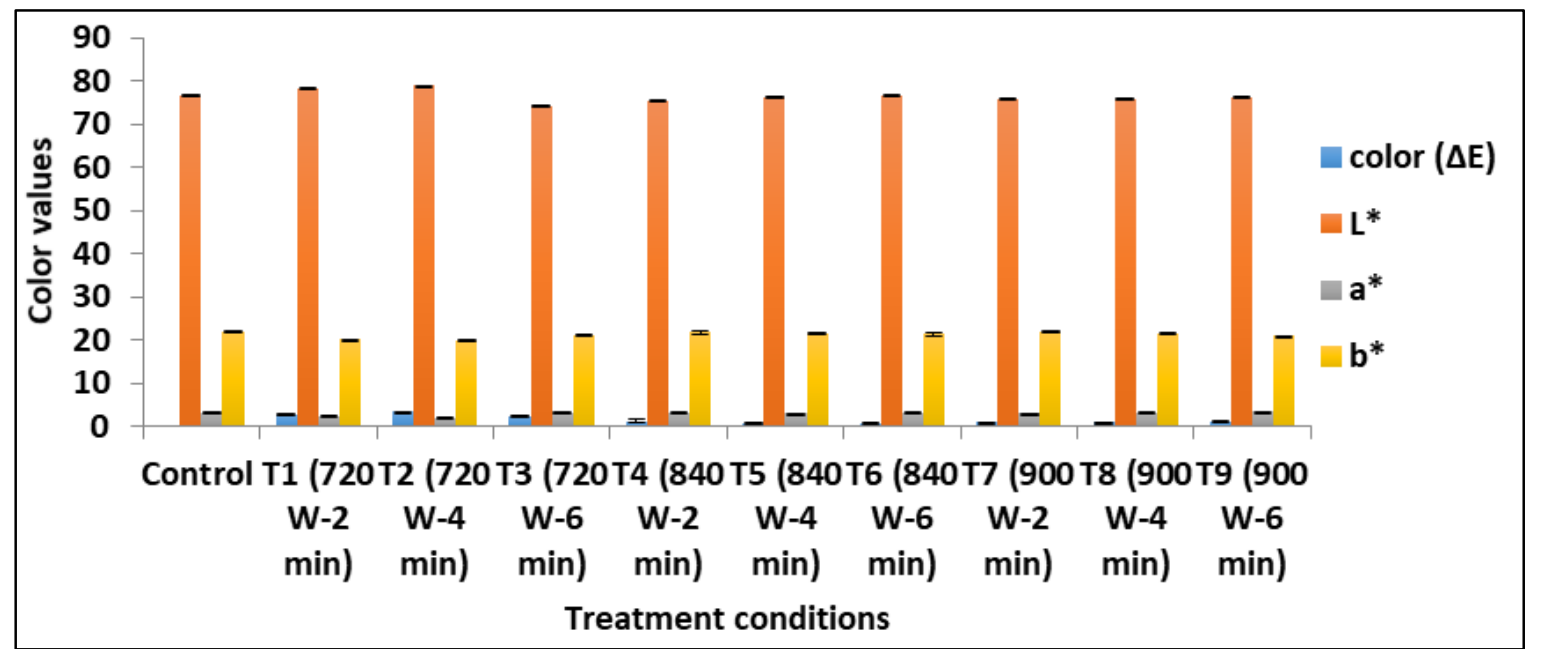

All the data are expressed in the form of mean \pm standard deviation; Means that do not share a common alphabet are significantly different $\mathrm{p} \geq 0.05$.

Fig 1: $L^{*}, a^{*}, b^{*}$ and $\Delta E$ values of microwave treated foxtail millet flour

Figure 1 explains the effect of microwave treatment on the color of untreated and microwave treated foxtail millet flour. The lowest $\Delta \mathrm{E}$ values along with closer $\mathrm{L}^{*}$ values to the control sample were observed in the treatment condition, 840 $\mathrm{W}$ for $6 \mathrm{~min}$.

On the other hand, $\mathrm{a}^{*}$ value similar to control was reported at $720 \mathrm{~W}$ and 6 min while $\mathrm{b}^{*}$ value was reported at $900 \mathrm{~W}$ and 2 min. The lowest values of $\mathrm{L}^{*}, \mathrm{a}^{*}$, and $\mathrm{b}^{*}$ with high $\Delta \mathrm{E}$ were observed during the treatment condition of $720 \mathrm{~W}$ power. The slight differences in color values might be caused by the transformation of flavanols in color pigments into intermediate compounds induced by a microwave treatment during heat treatment (Yadav, Kaur, et al., 2012) ${ }^{[21,22]}$.

Microwave parameters like treatment time and power used for treatment can have a significant impact on the degree of change in color parameters and these slight changed $\Delta \mathrm{E}$ may attribute to the formations of brown pigments with high and low molecular weights by a Millard reaction (Srinivas et al., 2020) ${ }^{[16]}$. 
3.1.3. Effect on Carr's index (CI) and Hausner ratio (HR): Carr's index and Hausner ratio exhibited no significant difference between the microwaves treated and control samples. Carr's index for the control sample was found to be $0.13 \pm 0.005$ while the lowest value, $0.10 \pm 0.019$ was at $720 \mathrm{~W}$ and $4 \mathrm{~min}$ treatment condition with the highest flowability. Carr's index also called compressibility index is a measurement of flowability of flour, i.e., flour with CI less than 15 has good flowability while above 35 shows bad flowability (Smita et al., 2019) ${ }^{[15]}$. In the present study, the lowest value for HR was reported at the treatment condition $720 \mathrm{~W}$ and $4 \mathrm{~min}$, similar to that of CI. Flour with HR greater than 1.35 has poor flow properties, while it is the reverse case in the present study, confirming the retaining of flow properties of flour upon microwave treatment as in the case of the control sample $(\mathrm{P}=0.684)$ (Hamdani et al., 2014) ${ }^{[3]}$.

Table 2: Carr's index and Hausner ratio of microwave treated foxtail millet flour

\begin{tabular}{|c|c|c|}
\hline Treatment conditions & Carr's index (CI) & Hausner ratio (HR) \\
\hline Control & $0.13 \pm 0.005^{\mathrm{a}}$ & $1.15 \pm 0.007^{\mathrm{a}}$ \\
\hline T1 (720 W-2 min) & $0.13 \pm 0.023^{\mathrm{a}}$ & $1.16 \pm 0.030^{\mathrm{a}}$ \\
\hline T2 (720 W-4 min) & $0.10 \pm 0.019^{\mathrm{a}}$ & $1.12 \pm 0.023^{\mathrm{a}}$ \\
\hline T3 (720 W-6 min) & $0.14 \pm 0.006^{\mathrm{a}}$ & $1.16 \pm 0.009^{\mathrm{a}}$ \\
\hline T4 $(840 \mathrm{~W}-2 \mathrm{~min})$ & $0.13 \pm 0.015^{\mathrm{a}}$ & $1.15 \pm 0.020^{\mathrm{a}}$ \\
\hline T5 $(840 \mathrm{~W}-4 \mathrm{~min})$ & $0.14 \pm 0.003^{\mathrm{a}}$ & $1.16 \pm 0.005^{\mathrm{a}}$ \\
\hline T6 $(840 \mathrm{~W}-6 \mathrm{~min})$ & $0.13 \pm 0.011^{\mathrm{a}}$ & $1.14 \pm 0.014^{\mathrm{a}}$ \\
\hline T7 $(900 \mathrm{~W}-2 \mathrm{~min})$ & $0.14 \pm 0.02^{\mathrm{a}}$ & $1.17 \pm 0.073^{\mathrm{a}}$ \\
\hline T8 $(900 \mathrm{~W}-4 \mathrm{~min})$ & $0.14 \pm 0.019^{\mathrm{a}}$ & $1.16 \pm 0.026^{\mathrm{a}}$ \\
\hline T9 $(900 \mathrm{~W}-6 \mathrm{~min})$ & $0.14 \pm 0.003^{\mathrm{a}}$ & $1.16 \pm 0.004^{\mathrm{a}}$ \\
\hline
\end{tabular}

All the data are expressed in the form of mean \pm standard deviation; Means that do not share a common alphabet are significantly different $p \geq 0.05$.

\subsection{Effect of microwave treatment on functional} properties

\subsubsection{Effect on water absorption and oil absorption} capacity

The oil absorption capacity of FMF was found to be decreased with microwave treatment while it is vice versa in the case of water absorption capacity. The lowest oil absorption capacity was noticed at 840 and $900 \mathrm{~W}$ when flour is treated for $6 \mathrm{~min}$. In the case of water absorption capacity, the highest water absorption capacity was noticed at treatment level $840 \mathrm{~W}$ and $6 \mathrm{~min}$, i.e., $1.58 \pm 0.047 \mathrm{~g} / \mathrm{g}$. Similar trends of oil and water absorption capacities were observed by Sahni and Sharma performed microwave treatment studies on alfa- alfa flour and reported similar trends of oil and water absorption capacities (Sahni \& Sharma, 2020) ${ }^{[12]}$.

Heat-induced protein denaturation results in the unfolding of protein molecules, followed by exposure to polar side chains. This leads to an increase in water absorption and a decrease in the oil absorption capacity of treated flour (Singh, 2001) ${ }^{[14]}$. An increase in water absorption capacity leads to increased water availability, which plays a major role in starch gelatinization and turns the final texture of cooked products. Decreased OAC can be attributed to the presence of a lesser amount of hydrophobic amino acids in the sample (Ashraf et al., 2012) ${ }^{[1]}$.

Table 3: Oil absorption and water absorption capacity of microwave treated foxtail millet flour

\begin{tabular}{|c|c|c|}
\hline Treatment & $\mathbf{O A C}(\mathbf{g} / \mathbf{g})$ & $\mathbf{W A C}(\mathbf{g} / \mathbf{g})$ \\
\hline Control & $1.63 \pm 0.030^{\mathrm{a}}$ & $1.15 \pm 0.061^{\mathrm{f}}$ \\
\hline T1 (720 W-2 min) & $1.45 \pm 0.033^{\mathrm{bc}}$ & $1.24 \pm 0.0184^{\mathrm{ef}}$ \\
\hline T2 (720 W-4 min) & $1.60 \pm 0.028^{\mathrm{a}}$ & $1.33 \pm 0.025^{\mathrm{de}}$ \\
\hline T3 (720 W-6 min) & $1.48 \pm 0.014^{\mathrm{b}}$ & $1.30 \pm 0.003^{\mathrm{de}}$ \\
\hline T4 (840 W-2 min) & $1.58 \pm 0.035^{\mathrm{a}}$ & $1.33 \pm 0.041^{\mathrm{de}}$ \\
\hline T5 (840 W-4 min) & $1.17 \pm 0.032^{\mathrm{e}}$ & $1.47 \pm 0.015^{\mathrm{bc}}$ \\
\hline T6 (840 W-6 min) & $1.15 \pm 0.032^{\mathrm{e}}$ & $1.58 \pm 0.047^{\mathrm{a}}$ \\
\hline T7 (900 W-2 min) & $1.38 \pm 0.016^{\mathrm{c}}$ & $1.26 \pm 0.020^{\mathrm{e}}$ \\
\hline T8 (900 W-4 min) & $1.28 \pm 0.031^{\mathrm{d}}$ & $1.38 \pm 0.042^{\mathrm{cd}}$ \\
\hline T9 (900 W-6 min) & $1.15 \pm 0.029^{\mathrm{e}}$ & $1.48 \pm 0.012^{\mathrm{b}}$ \\
\hline
\end{tabular}

All the data are expressed in the form of mean \pm standard deviation; Means that do not share a common alphabet are significantly different $p \geq 0.05$.

\subsubsection{Effect of microwave treatment on solubility and swelling power}

Swelling power of the microwave treated flour found to be decreased with an increase in power level and treatment time, except at $840 \mathrm{~W}-2$ min.

Various studies confirmed the negative correlation between the swelling power and moisture content, i.e increase in water absorption by flour results in less swelling power (Li et al., 2019) ${ }^{[6]}$.

The above inference can be attributed to the enhancement of intra and intermolecular forces upon microwave treatment, i.e., the formation of hydrogen bonding of water with various hydroxyl groups. These phenomena result in lesser availability of water to the amylose and amylopectin, thus decreasing the swelling power of the sample (Luo et al., 2006) ${ }^{[7]}$.

The solubility of flour increased with microwave treatment when compared to untreated samples. The solubility of flour increased enormously from $17.94 \pm 1.81 \%$ to $41.96 \pm 1.67 \%$ at $840 \mathrm{~W}$ and 2 min treatment conditions, while it was in the range of $20 \%$ with other treatment conditions.

The degree of depolymerization and structural weakening of starch granules that occur due to microwave treatment is responsible for the solubility of flour (Obadi et al., 2016) ${ }^{[10]}$. 
Table 4: Solubility and swelling power of microwave treated foxtail millet flour

\begin{tabular}{|c|c|c|}
\hline Treatment & $\mathbf{S ~ ( \% )}$ & $\mathbf{S P}(\mathbf{g} / \mathbf{g})$ \\
\hline Control & $17.94 \pm 1.81^{\mathrm{de}}$ & $38.39 \pm 1.59^{\mathrm{de}}$ \\
\hline T1 $(720 \mathrm{~W}-2 \mathrm{~min})$ & $27.20 \pm 1.50^{\mathrm{b}}$ & $38.82 \pm 0.82^{\mathrm{b}}$ \\
\hline T2 $(720 \mathrm{~W}-4 \mathrm{~min})$ & $21.70 \pm 0.19^{\text {cd }}$ & $34.07 \pm 0.51^{\mathrm{de}}$ \\
\hline T3 $(720 \mathrm{~W}-6 \mathrm{~min})$ & $26.38 \pm 1.20^{\mathrm{b}}$ & $36.90 \pm 1.46^{\mathrm{bc}}$ \\
\hline T4 $(840 \mathrm{~W}-2 \mathrm{~min})$ & $41.96 \pm 1.67^{\mathrm{a}}$ & $48.71 \pm 0.30^{\mathrm{a}}$ \\
\hline T5 $(840 \mathrm{~W}-4 \mathrm{~min})$ & $19.67 \pm 0.63^{\text {cde }}$ & $35.15 \pm 0.66^{\mathrm{cd}}$ \\
\hline T6 $(840 \mathrm{~W}-6 \mathrm{~min})$ & $20.55 \pm 1.73^{\text {cde }}$ & $32.23 \pm 0.59^{\mathrm{de}}$ \\
\hline T7 $(900 \mathrm{~W}-2 \mathrm{~min})$ & $18.47 \pm 1.13^{\text {cde }}$ & $34.84 \pm 1.36^{\text {cde }}$ \\
\hline T8 $(900 \mathrm{~W}-4 \mathrm{~min})$ & $22.85 \pm 1.63^{\mathrm{bc}}$ & $34.80 \pm 0.40^{\text {cde }}$ \\
\hline T9 $(900 \mathrm{~W}-6 \mathrm{~min})$ & $16.47 \pm 2.48^{\mathrm{e}}$ & $32.57 \pm 0.93^{\mathrm{de}}$ \\
\hline
\end{tabular}

All the data are expressed in the form of mean \pm standard deviation; Means that do not share a common alphabet are significantly different $p \geq 0.05$.

\section{Conclusion}

The microwave pre-treatment prior to the milling of foxtail millets results in significant changes of functional properties (OAC, WAC, SP, and S) of flour $(p<0.05)$. The color values of MW treated sample flours were slightly changed with an acceptable limit as compared with the untreated sample. But, there was no significant effect on the bulk density, tapped density, HR, and CI values ( $p>0.05)$. These results indicate that microwave heating as a pre-treatment can effectively enhance the functional properties of millet flours without affecting its physical parameters. The flour from microwave treated foxtail millet can exploit its applications in different food process purposes which can certainly help in the value addition of under-utilized foxtail millet.

\section{Acknowledgment}

Authors grateful to thank the Indian Institute of Food Processing Technology for providing a laboratory facility.

\section{References}

1. Ashraf S, Saeed SMG, Sayeed SA, Ali R. Impact of microwave treatment on the functionality of cereals and legumes. International Journal of Agriculture and Biology 2012;14(3):365-370.

2. Devraj L, Natarajan V, Vadakkeppulpara Ramachandran S, Manicakam L, Sarvanan S. Influence of microwave heating as accelerated aging on physicochemical, texture, pasting properties, and microstructure in brown rice of selected Indian rice varieties. Journal of Texture Studies, 2020;51(4):663-679. https://doi.org/10.1111/jtxs.12522

3. Hamdani A, Rather SA, Shah A, Gani A, Wani SM, Masoodi FA, et al. Physical properties of barley and oats cultivars grown in high altitude Himalayan regions of India. Journal of Food Measurement and Characterization 2014;8(4):296-304. https://doi.org/10.1007/s11694-0149188-1

4. Karuppasamy P, Malathi D, Banumathi P, Varadharaju N, Seetharaman K. Evaluation of quality characteristics of bread from kodo, little and foxtail millets. International Journal of Food and Nutritional Sciences 2013;2(2):35-39.

5. Khushbu S, Sunil CK, Chidanand DV, Jaganmohan R. Effect of particle size on compositional, structural, rheological, and thermal properties of shallot flour as a source of thickening agent. Journal of Food Process Engineering

2020;43(3):1-13. https://doi.org/10.1111/jfpe.13237

6. Li Y, Hu A, Wang X, Zheng J. Physicochemical and in vitro digestion of millet starch: Effect of moisture content in microwave. International Journal of Biological Macromolecules 2019;134:308-315. https://doi.org/10.1016/j.ijbiomac.2019.05.046

7. Luo Z, He X, Fu X, Luo F, Gao Q. Effect of microwave radiation on the physicochemical properties of normal maize, waxy maize and amylomaize V starches. Starch/Staerke 2006;58(9):468-474. https://doi.org/10.1002/star.200600498

8. Naik M, Natarajan V, Rawson A, Rangarajan J, Manickam L. Extraction kinetics and quality evaluation of oil extracted from bitter gourd (Momardica charantia L.) seeds using emergent technologies. Lwt 2021;140:110714.

https://doi.org/10.1016/j.lwt.2020.110714

9. Nikitha M, Natarajan V. Properties of South-Indian rice cultivars: physicochemical, functional, thermal and cooking characterisation. Journal of Food Science and Technology 2020;57(11):4065-4075. https://doi.org/10.1007/s13197-020-04440-3

10. Obadi M, Zhu KX, Peng W, Ammar AF, Zhou HM. Effect of ozone gas processing on physical and chemical properties of wheat proteins. Tropical Journal of Pharmaceutical Research 2016;15(10):2147-2154. https://doi.org/10.4314/tjpr.v15i10.13

11. Obadi M, Zhu KX, Peng W, Sulieman AA, Mohammed $\mathrm{K}$, Zhou HM, et al. Effects of ozone treatment on the physicochemical and functional properties of whole grain flour. Journal of Cereal Science 2018;81:127-132. https://doi.org/10.1016/j.jcs.2018.04.008

12. Sahni P, Sharma S. Influence of processing treatments on cooking quality, functional properties, antinutrients, bioactive potential and mineral profile of alfalfa. Lwt 2020;132:109890. https://doi.org/10.1016/j.lwt.2020.109890

13. Sharma N, Goyal SK, Alam T, Fatma S, Chaoruangrit A, Niranjan $\mathrm{K}$, et al. Effect of high pressure soaking on water absorption, gelatinization, and biochemical properties of germinated and non-germinated foxtail millet grains. Journal of Cereal Science 2018. https://doi.org/10.1016/j.jcs.2018.08.013

14. Singh U. Functional properties of grain legume flours. Journal of Food Science and Technology (Mysore) 2001;38(3):191-199.

15. Smita M, Bashir M, Haripriya S. Physicochemical and functional properties of peeled and unpeeled coconut haustorium flours. Journal of Food Measurement and Characterization https://doi.org/10.1007/s11694-018-9919-9

16. Srinivas Y, Mathew SM, Kothakota A, Sagarika N, Pandiselvam R. Microwave assisted fluidized bed drying of nutmeg mace for essential oil enriched extracts: An assessment of drying kinetics, process optimization and quality. Innovative Food Science and Emerging Technologies https://doi.org/10.1016/j.ifset.2020.102541

17. Sunil CK, Chacko N. Microwave Assisted De-husking of Foxtail Millet. Journal of Agricultural Engineering 2019;55(4):21-33.

18. Sunil CK, Venkatachalapathy N. Engineering properties of foxtail millet (Setaria italic L) as a function of moisture content. Trends in Biosciences 2017;10(20):3990-3996.

19. Sunil CK, Venkatachalapathy N, Shanmugasundaram S, Loganathan M. Engineering properties of foxtail millet (Setaria italic L): Variety-HMT 1001. International 
Journal of Science, Environment and Technology 2016;5(2):632-637.

20. Umesha G, Manjunatha MH, Kadalli G. Effect of Different Moisture Levels on Physical Properties and Milling Quality of Paddy Varieties. Environment \& Ecology 2015;33(3A):1361-1365.

21. Yadav DN, Anand T, Kaur J, Singh AK. Improved Storage Stability of Pearl Millet Flour Through Microwave Treatment. Agricultural Research 2012;1(4):399-404. https://doi.org/10.1007/s40003-0120040-8

22. Yadav DN, Kaur J, Anand T, Singh AK. Original article Storage stability and pasting properties of hydrothermally treated pearl millet flour 2012, 1-6. https://doi.org/10.1111/j.1365-2621.2012.03131.x 